This PDF is a selection from an out-of-print volume from the National Bureau of Economic Research

Volume Title: Corporate Takeovers: Causes and Consequences

Volume Author/Editor: Alan J. Auerbach, ed.

Volume Publisher: University of Chicago Press

Volume ISBN: 0-226-03211-6

Volume URL: http://www.nber.org/books/auer88-1

Publication Date: 1988

Chapter Title: The Impact of Firm Acquisitions on Labor

Chapter Author: Charles Brown, James L. Medoff

Chapter URL: http://www.nber.org/chapters/c2051

Chapter pages in book: (p. 9 - 32) 


\title{
The Impact of Firm Acquisitions on Labor
}

\author{
Charles Brown and James L. Medoff
}

\subsection{Introduction}

The impact of firm acquisitions on the value of both the acquiring and the acquired firm has been the subject of a large and growing body of research (see, for example, Asquith, Bruner, and Mullins 1986; and in this volume, Franks, Harris, and Mayer; Hall; and Ruback). But there are no similar systematic investigations of the impact of corporate acquisitions on labor. A lack of concern about how labor fares in a takeover cannot be the reason for the absence of statistical analysis of this question; indeed, the popular press (and, presumably, its readers) are fascinated by the subject.

The public's perception is conditioned by a relatively small number of highly publicized and extremely hostile takeovers. What comes to mind immediately is the elaborate history of Carl Icahn, Frank Lorenzo, and the airline industry. Also widely covered was the extensive employment loss-estimated at 25,000 jobs-associated with the takeover attempts made on two major food store chains, Safeway Stores and Lucky Stores.

Organized labor has explicitly stated its concern that acquisitions are bad for workers (AFL-CIO 1987, El):

Charles Brown is professor of economics, Department of Economics, and program director, Survey Research Center, Institute for Social Research, at the University of Michigan, and a research associate of the National Bureau of Economic Research. James L. Medoff is professor of economics at Harvard University and a research associate of the NBER.

The authors are grateful to Judith Connor, Steven Heeringa, John Jackson, and Charles Lake for help with the MESC data; to Judith Connor for skillful programming; and to Marsha Silverberg for research assistance. They also acknowledge helpful suggestions by Geoffrey Carliner and Henry S. Farber, the commentators, and by several other conference participants. 
Workers and their unions have a vital interest in the corporate takeover issue. Corporate mergers, takeovers, and leveraged buy-outs often have serious effects on jobs, wages, and working conditions.

The general public exhibits similar concern. A recent survey by Louis Harris and Associates revealed that 58 percent of the sample believes that hostile takeovers do more harm than good. Moreover, when respondents were asked which one group they thought ought to be protected most from being hurt in a hostile takeover, 63 percent said "employees" (Louis Harris and Associates, 1987).

Despite these fears, it is not obvious that acquisitions necessarily lower wages and employment. One reason for being skeptical about any widespread injury to workers from acquisitions is the highly unrepresentative set of takeovers that has received the most publicity.

Another reason for skepticism lies in an understanding of the various motives for acquisitions. First, acquisitions may occur because of differences in opinion, with the buyer thinking the acquisition more valuable than the seller. Second, acquisitions may occur because a group outside the firm believes it can manage the firm more efficiently than current management (Jensen 1984). Third, acquisitions may occur because the sale may permit the abrogation of rules governing employment and earnings at smaller costs to employee morale and the firm's reputation (Shleifer and Summers, in this volume).

The first possible reason for an acquisition does not imply impending disaster for labor: to the contrary, if the acquiring optimist is correct, increased prosperity for workers might be just around the corner. The second reason also need not be a harbinger of bad times: better management might lead to more and better jobs. This is particularly true if the new managers have better access to capital markets for expanding the operation. The third reason, however, can be expected to be associated with worse conditions for workers. Although these worse conditions are usually blamed on the acquiring owners or managers, they typically reflect some significant change in market conditions, such as deregulation in the airline industry. Indeed, if the acquisition shocks the workers into accepting changes in work rules, employment and wages could actually be improved by the acquisition.

When the dust settles, does labor win or lose from the typical acquisition? In particular, what happens to wages and employment? In this paper, we address these questions. To do so, we use data on the employment and wages of firms in Michigan compiled from unemployment insurance (ES202) records kept by the Michigan Employment Security Commission. The MESC data file has several useful characteristics: consistent longitudinal data for six and one-half years (1978:III1984:IV); the inclusion of small firms likely to be absent from other data files; and the identification of acquisitions as part of the book- 
keeping needed to run the unemployment insurance (UI) system. Its disadvantages are the result of its being limited to a single state: Michigan is not representative of the entire nation, the data do not reflect what is happening in other locations of multistate companies, and the data chart relatively few of the mega-acquisitions which dominate public attention. The data also do not allow us to distinguish between friendly and hostile takeovers. Hence, our findings apply to acquisitions in general, and not necessarily to hostile takeovers.

In section 1.2 we describe the data in greater detail. Our twin goals here are to specify the issues that arise in distinguishing between mergers and other sorts of acquisitions and to give an overview of the characteristics of firms that were and were not involved in acquisitions in the years in question. In section 1.3 we describe our methods of analysis. Sections 1.4 and 1.5 document our measures of the impact of mergers on wages and employment. In the case of mergers we compare postmerger wages and employment to the wages and employment of the two partners taken together. The longitudinal data provide several years of preacquisition information to serve as a base for the analysis and several years of subsequent data to go beyond the very short-term effects. In general, we find small (and sometimes positive) changes in wages and employment following an acquisition. In section 1.6 we summarize our findings and discuss options for future work.

\subsection{The Data}

The file of MESC records available at the Institute for Social Research at the University of Michigan includes data on over 200,000 firms over the period 1978:III through 1984:IV.' Employment data are calculated monthly, and total payroll (not UI-taxable payroll) data are calculated quarterly. As part of the normal bookkeeping of the UI system, MESC identifies situations in which the assets of one firm (a "predecessor") are acquired by another (a "successor"). The file used in this paper does not include predecessors as separate firms, but it includes predecessor employment and payroll prior to the acquisition in separate "predecessor" fields on the successor firm's longitudinal record. ${ }^{2}$

In thinking about the impact of acquisitions on employment and wages, it is important to distinguish among several different types of acquisitions:

1. Firm A changes ownership without being integrated with any other firm;

2. Firm A purchases the assets of firm B without absorbing its work force;

3. Firm A purchases firm B and (at least initially) absorbs (most of) firm B's workers, or firm A and firm B combine to form firm C, 
with (at least initially) firm $\mathrm{C}$ including (most of) the workers of firms $\mathrm{A}$ and $\mathrm{B}$.

The key to distinguishing among these types of acquisitions is the pattern of predecessor $(P)$ and successor $(S)$ employment over time. Let $T$ be the period of the acquisition, the last period in which $P$ is positive. In situation 1 we would observe this pattern:

$\begin{array}{lccccccccc}\text { Month } & 1 & 2 & \ldots & T-1 & T & T+1 & T+2 & T+3 & \ldots \\ \begin{array}{l}\text { Predecessor } \\ \quad \text { employment }\end{array} & P_{1} & P_{2} & \ldots & P_{T-1} & P_{T} & 0 & 0 & 0 & \ldots \\ \begin{array}{l}\text { Successor } \\ \quad \text { employment }\end{array} & 0 & 0 & \ldots & 0 & 0 & S_{T+1} & S_{T+2} & S_{T+3} & \ldots \\ \quad \text { employm }\end{array}$

We might expect $S_{T+1}=P_{T}$ if the firm's employment was stable. In any case, the pattern of zero employment for the successor through $T$ makes this case easy to distinguish from the others.

In situation 2 we should observe:

$\begin{array}{lccccccccc}\text { Month } & 1 & 2 & \ldots & T-1 & T & T+1 & T+2 & T+3 & \ldots \\ \begin{array}{l}\text { Predecessor } \\ \text { employment }\end{array} & P_{1} & P_{2} & \ldots & P_{T-1} & P_{T} & 0 & 0 & 0 & \ldots \\ \begin{array}{c}\text { Successor } \\ \quad \text { employment }\end{array} & S_{1} & S_{2} & \ldots & S_{T-1} & S_{T} & S_{T+1} & S_{T+2} & S_{T+3} & \ldots\end{array}$

Because the successor is acquiring the assets but not the workers of the predecessor, we expect $S_{T+1} \simeq S_{T}$.

Finally, situation 3-at least mergers of two firms doing business in Michigan-should generate this pattern: ${ }^{3}$

$\begin{array}{lccccccccc}\text { Month } & 1 & 2 & \ldots & T-1 & T & T+1 & T+2 & T+3 & \ldots \\ \begin{array}{l}\text { Predecessor } \\ \text { employment }\end{array} & P_{1} & P_{2} & \ldots & P_{T-1} & P_{T} & 0 & 0 & 0 & \ldots \\ \begin{array}{c}\text { Successor } \\ \quad \text { employment }\end{array} & S_{1} & S_{2} & \ldots & S_{T-1} & S_{T} & S_{T+1} & S_{T+2} & S_{T+3} & \ldots\end{array}$

Unless employment is growing or fluctuating significantly, $S_{T+1}$ should approximately equal $P_{T}+S_{T}$.

There are three problems in classifying acquisitions with these data. First, we have no information on mergers between in-state and out-ofstate firms. When an in-state firm is acquired by an out-of-state firm, there will be no record of the successor prior to the acquisition, and so it will look like a type 1 acquisition. Conversely, when an out-ofstate firm is acquired by an in-state firm, there is no record of the merger at all.

The second problem lies in distinguishing between acquisitions in which the successor acquires the predecessor's workers and acquisitions in. which the successor does not. The only evidence to distinguish 
between cases 2 and 3 is whether $S_{T+1} \simeq S_{T}$, or $S_{T+1} \simeq P_{T}+S_{T}$. If $P_{T}$ and $S_{T}$ are unstable and/or $P_{T}$ is small, it will be hard to identify true mergers. To see this, consider this record:

\begin{tabular}{|c|c|c|c|c|c|c|c|c|}
\hline Month & 1 & 2 & & $T-1$ & $T$ & $T+1$ & $T+2$ & $T+3$ \\
\hline $\begin{array}{l}\text { Predecessor } \\
\text { employment }\end{array}$ & 4 & 3 & . & 5 & 4 & 0 & 0 & 0 \\
\hline $\begin{array}{l}\text { Successor } \\
\text { employment }\end{array}$ & 100 & 101 & $\ldots$ & 105 & 107 & 110 & 110 & 110 \\
\hline
\end{tabular}

One interpretation is that the two firms merged in month $T$, creating a firm with 111 employees, all but one of whom was employed in the next month. The other interpretation is that the successor expanded by 3 workers at the same time as it acquired the assets (but not the employees) of the predecessor.

In the tables below we identify as type 3 acquisitions or "mergers" those records that have positive successor employment prior to $T$ and

(a) $\frac{S_{T+1}-\left(S_{T}+P_{T}\right)}{P_{T}}>-0.50$, or equivalently, $\frac{S_{T+1}-S_{T}}{P_{T}}>0.50$

$$
P_{T}>10
$$

Condition (a) says the successor must grow by at least 50 percent of the predecessor's employment. Condition (b) requires that the predecessor be large enough that condition (a) is practically meaningful. ${ }^{4}$ Conditions like these are needed if artificial inflation of the merger count is to be avoided. ${ }^{5}$ The particular cutoffs are, to be sure, arbitrary.

A third problem is that the predecessor-successor relationship applies to reorganizations as well as to acquisitions. It is difficult to distinguish reorganizations from type 1 acquisitions (simple sales) because the pattern of predecessor and successor employment would be exactly the same. A "type of business" (for example, proprietorship, partnership, corporation) field is available, however, and we can distinguish cases where the type of business changes. We call cases that otherwise look like simple sales but show a change in the type of business code "reorganizations." The distinction between "simple sales" and "reorganizations" is not as clean as we would like, since some restructuring does not involve a change of business type while some sales are accompanied by such a change.

To summarize, type 1 acquisitions are those for which there is no successor employment prior to $T$ and for which the "type of business" remains the same. Type 2 acquisitions are those for which there is positive successor employment prior to $T$ but which do not satisfy the two conditions (a) and (b) above. Type 3 acquisitions are those for which there is positive successor employment prior to $T$ and which do satisfy those two conditions. We will sometimes refer to types 1, 2, 
and 3 as "simple sales," "assets-only sales," and "mergers," respectively. We treat "reorganizations" as a separate category, though they are not our primary focus. We ignore those acquisitions that occurred in 1978 or 1984:IV because the predecessor and successor data on them are scant.

Because acquisitions - and especially mergers-are fairly rare events but the MESC file is enormous, we constructed an "extract file" consisting of all firms with nonzero predecessor fields and a 20 percent sample of other firms. Most of our analysis, however, is based on a smaller file, consisting of observations that had relatively complete data. More specifically, we included an observation in what we call the "clean-data file" only if there was some employment and payroll data in each year.

Table 1.1 offers an overview of the extract file and the clean-data file. Two findings shown in the table are striking. First, even remembering that the "no predecessor" cases represent a 20 percent subsample, the relative frequency of "reorganizations" compared to nopredecessor firms over the six years 1979-84 is striking. (We also found the frequency of type 2 (assets only) acquisitions surprisingly high.) The second striking finding in the table is that the clean-data file is so much smaller than the complete extract. There are two reasons for this. First, birth and death rates of firms are quite high, and they show up as "missing" data in the years before a birth or after a death. Connor, Heeringa, and Jackson (1985) note that both births and deaths are very common in these data. We will have a little to say about deaths later in the paper. Second, there are some missing data, although we have somewhat reduced their influence by eliminating only observations for which the data are missing for an entire year.

Table 1.2 divides the extract and clean-data files by broad industry type. The distribution of observations in the two files is quite similar,

Table 1.1

An Overview of the Extract File and the Clean-Data File

\begin{tabular}{lcc}
\hline & \multicolumn{2}{c}{ Number of Observations in: } \\
\cline { 2 - 3 } Type of Firm & $\begin{array}{c}\text { Complete } \\
\text { Extract File }\end{array}$ & $\begin{array}{c}\text { Clean-Data } \\
\text { File }\end{array}$ \\
\hline No predecessor & 34.689 & 14,005 \\
Type 1 acquisition: simple sale & 7,905 & 4,055 \\
Type 2 acquisition: assets-only sale & 3,138 & 2,391 \\
Type 3 acquisition: merger & 479 & 438 \\
Reorganization & 17,578 & 9,363 \\
1978 or 1984:IV acquisition $\dagger$ & 4,155 & 0 \\
Total & 67,944 & 30,252 \\
\hline
\end{tabular}

†This category also includes a small number of acquisitions for which missing data made it difficult to code the type of acquisition. 


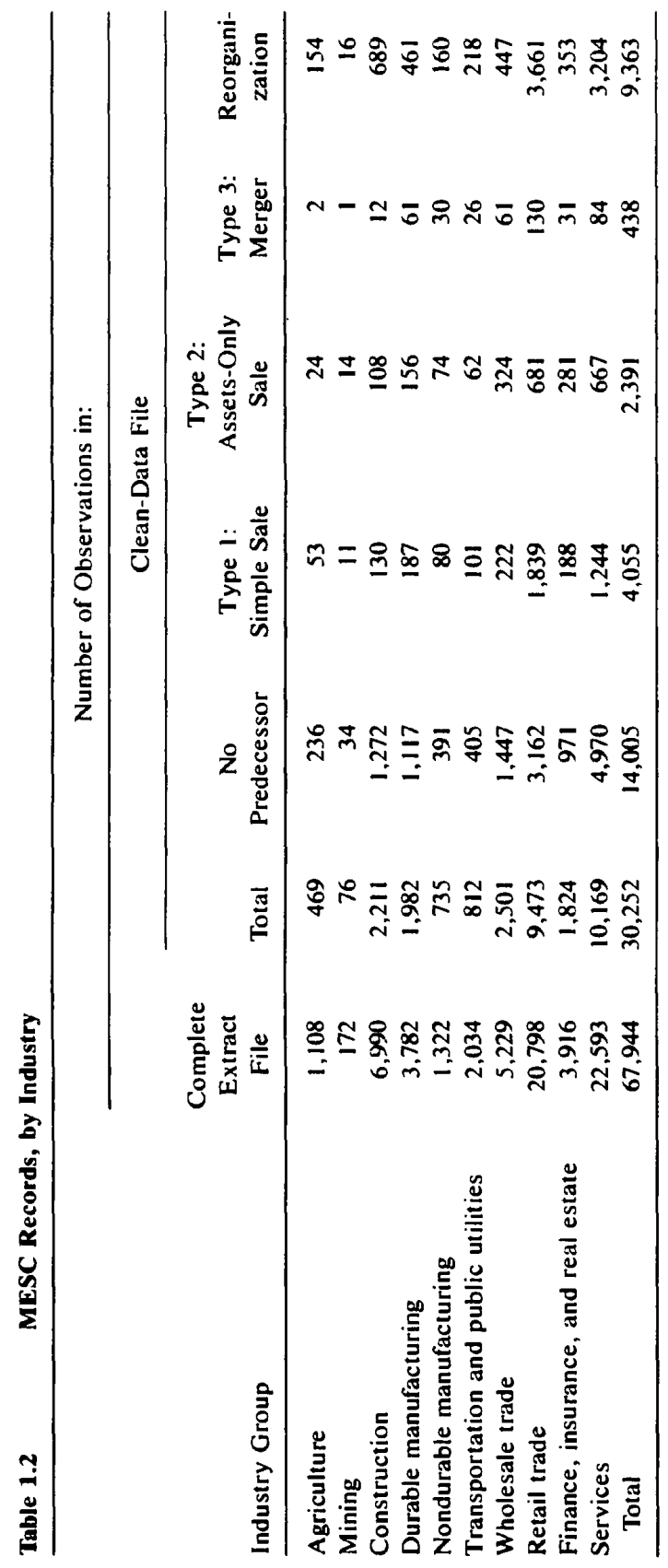




\begin{tabular}{|c|c|c|c|c|}
\hline \multirow[b]{3}{*}{ Type of Acquisition } & \multicolumn{4}{|c|}{ Average Number of Employees } \\
\hline & \multicolumn{2}{|c|}{ Extract File } & \multicolumn{2}{|c|}{ Clean-Data File } \\
\hline & 1978 & 1984 & 1978 & 1984 \\
\hline No predecessor & $\begin{array}{r}22 \\
(284) \\
{[21,535]}\end{array}$ & $\begin{array}{r}20 \\
(233) \\
{[23,186]}\end{array}$ & $\begin{array}{r}29 \\
(350) \\
{[14,005]}\end{array}$ & $\begin{array}{r}27 \\
(296) \\
{[14,005]}\end{array}$ \\
\hline Type 1 acquisition: simple sale & $\begin{array}{r}17 \\
(114) \\
{[6,166]}\end{array}$ & $\begin{array}{r}17 \\
(97) \\
{[5,376]}\end{array}$ & $\begin{array}{r}21 \\
(140) \\
{[4,055]}\end{array}$ & $\begin{array}{r}20 \\
(110) \\
{[4,055]}\end{array}$ \\
\hline Type 2 acquisition: assets-only sale & $\begin{array}{c}114 \\
(1,672) \\
{[2,815]}\end{array}$ & $\begin{array}{r}99 \\
(1,082) \\
{[2,665]}\end{array}$ & $\begin{array}{c}130 \\
(1,813) \\
{[2,391]}\end{array}$ & $\begin{array}{r}109 \\
(1,142) \\
{[2,391]}\end{array}$ \\
\hline Type 3 acquisition: merger & $\begin{array}{c}255 \\
(740) \\
{[462]}\end{array}$ & $\begin{array}{c}262 \\
(708) \\
{[451]}\end{array}$ & $\begin{array}{c}264 \\
(758) \\
{[438]}\end{array}$ & $\begin{array}{c}268 \\
(717) \\
{[438]}\end{array}$ \\
\hline Reorganization & $\begin{array}{r}9 \\
(65) \\
{[12,814]}\end{array}$ & $\begin{array}{r}10 \\
(61) \\
{[13,194]}\end{array}$ & $\begin{array}{r}10 \\
(74) \\
{[9,363]}\end{array}$ & $\begin{array}{r}11 \\
(72) \\
{[9,363]}\end{array}$ \\
\hline
\end{tabular}

Note: Standard deviations are in parentheses and sample sizes in brackets below the means.

with the clean-data file having proportionately fewer construction firms and more manufacturing firms than the extract file from which it was derived. The three types of acquisitions are also spread broadly across industries.

Table 1.3 shows the average level of employment in the firms in the two files, categorized by the type of acquisition. Our employment variable includes the employment of both partners in cases where an acquisition occurred. The mean value for 1978 excludes those cases in the extract file where employment in 1978 was zero (missing); the mean value for 1984 similarly excludes observations with zero (missing) 1984 employment.

A comparison between the mean levels of employment in the extract file and in the clean-data file shows that average firm size is larger in the latter. This is exactly what one would expect, because births and deaths are more common among small firms than among large ones. Comparing the number of firms and the mean employment by type of acquisition brings out an important but less obvious fact. Although the average size of firms in type 1 acquisitions is small (17 workers, in the 1984 figures from the extract file), there are many such firms. Type 2 firms are larger, but there are proportionately fewer of them. Type 3 acquisitions (mergers) involve still larger firms, and here there are far 
fewer of them. Overall, the 1984 data from the extract file show there were roughly 85,000 workers employed in firms involved in type 1 acquisitions; 265,000 workers in type 2 acquisitions; and 115,000 workers in type 3 acquisitions (mergers). After taking account of the fact that the no-predecessor firms in table 1.3 are a 20 percent sample, we calculate that roughly 3,9 , and 4 percent, respectively, of workers in Michigan worked for firms involved in the three types of acquisitions in this period.

Finally, table 1.4 presents information about employment levels at the predecessor and successor firms, measured three months before the acquisition, and at the combined entity one month afterward. Three conclusions stand out. First, the predecessors in type 1 and type 2 acquisitions are small (averaging 20 workers and 11 workers, respectively), while the acquired firms in type 3 acquisitions (mergers) are on average medium-size ( 78 workers). Second, as one might expect, the successor (acquiring) firms are typically larger than the predecessors. Third, on average type 2 successors do not grow $\left(S_{T+1}-S_{T}=-2\right)$, despite having acquired the assets of predecessors with an average of 11 workers, whereas type 3 successors grow by nearly all the employment at the acquired firm $\left(S_{r+1}-S_{T}=79 ; P_{T}=78\right)$. In part, this last contrast follows from the definition of type 2 and type 3 acquisitions, but it is sharper than one might have guessed on purely definitional grounds.

\subsection{Method of Analysis}

To assess the relationship between changes in ownership and changes in wages and employment, we will compare firms involved in acquisitions in year $T$ with the much larger set of firms that were not involved

Table 1.4

Average Employment at Predecessors and Successors

\begin{tabular}{lccc}
\hline & \multicolumn{3}{c}{ Average Employment } \\
\cline { 2 - 4 } Type of Acquisition & $P_{T-3}$ & $S_{T-3}$ & $S_{T+1}$ \\
\hline Type I acquisition: simple sale & 20 & - & 21 \\
Type 2 acquisition: assets-only sale & $(126)$ & 107 & $(120)$ \\
Type 3 acquisition: merger & 11 & $(970)$ & 105 \\
& $(57)$ & 199 & 278 \\
Reorganization & 78 & $(707)$ & $(781)$ \\
& $(169)$ & - & 11 \\
\hline
\end{tabular}

Note: Standard deviations are in parentheses below means. 
in any acquisitions (that is, that had zero predecessor employment) throughout the sample period. ${ }^{6}$ Our wage equation is:

$$
\ln W_{T+j}=\sum_{t=1978}^{B} \alpha_{j l} \ln E_{t}+\sum_{t=1978}^{B} \beta_{j l} \ln W_{t}+\sum_{k=1}^{4} \gamma_{j k} D_{k}+\epsilon_{j},
$$

where $W$ is the payroll per worker (per month); $E$ is employment (averaged over all months where positive employment is reported); $B$ is a "base year" either one or two years prior to $T$; and $D_{k}$ is a dummy variable that equals one when the firm is involved in a type $k$ acquisition $(k=1,2,3)$ or reorganization $(k=4)$ in year $T$, and zero otherwise. Not shown explicitly in equation (1) are one-digit industry dummy variables, which are added to each equation. For each acquisition year $T$, separate equations are estimated for each year $T+j$, for $j=0$ through $T+j=1984$ (for example, for $T=1981$ we have four equations, one for each of the years 1981-84).

Our employment equation is slightly more complicated:

$$
E_{T+j}=\sum_{t=1978}^{B} \alpha^{\prime} \mathrm{jt} E_{t}+\sum_{i=1978}^{B} \beta_{j t}^{\prime} \ln W_{t}+\sum_{k=1}^{4} \gamma_{j k}^{\prime} D_{k} \bar{E}+\epsilon_{j}^{\prime}
$$

where $\bar{E}$ is the firm's average employment in the years prior to the merger. Interacting $D_{k}$ with $\bar{E}$ means that the impact of the various types of acquisitions is proportional to the premerger level of employment rather than being a fixed number of workers for all firm sizes. ${ }^{7}$ We weight the observations to produce a homoskedastic error term. ${ }^{8}$ We use $E$ rather than $\ln E$ as our dependent variable because it allows us to consider (in section 1.5) the impact of adding to the clean-data sample those firms that appear to have "died" after year $T$, by treating them as having $E_{T+j}=0$.

The ideas underlying these equations are borrowed from the literature that evaluates the impact of employment-training programs on individuals' earnings and employment (see, for example, Bloch 1979). Holding constant the history of the firm prior to $T$, we ask whether firms involved in changes of ownership had significantly different wages (or employment) $j$ years thereafter. 9

Using $T-1$ as the base year is the natural choice in our framework. The choice of year $T-2$ is motivated by the possibility that firms involved in mergers in year $T$ were subject to unusual transitory shocks in the previous year, from which they would anyway recover. Using $T-2$ as the base year ignores those shocks in predicting outcomes in $T+j$ and so essentially treats the $T-1$ shock as transitory (Ashenfelter 1978). 
In the results reported in the next section we study (separately) firms involved in acquisitions in 1981 and in 1982. These middle-of-the-sample years were chosen to ensure several years of data after $T$ (to evaluate the consequences of acquisitions) and several years before $T$ (to control accurately for prior conditions). In each case our "control group" consists of the firms not involved in an acquisition at any point between 1978 and 1984; we exclude altogether those firms that were involved in acquisitions in one of the other years.

\subsection{Wage Equations}

The key results from estimating equation (1) for $T=1981$ are presented in table 1.5. The top half of the table uses 1980 as the base year, while the bottom half uses 1979. Each column of the table represents the predicted employment for the year shown. Only the coefficients of the four dummy variables are reported, although each set of four coefficients comes from a (separate) equation with lagged wages and employment and the industry dummy variables included.

Table 1.5

Average-Wage Equations for the 1981 Acquisitions

\begin{tabular}{|c|c|c|c|c|c|c|c|}
\hline \multirow[b]{2}{*}{ Control Variable } & \multirow{2}{*}{$\begin{array}{l}\text { Base } \\
\text { Year }\end{array}$} & \multirow{2}{*}{$\begin{array}{c}\text { Acquisition } \\
\text { Variable } \dagger\end{array}$} & \multicolumn{5}{|c|}{ Proportional Effect on Average Wage in: } \\
\hline & & & 1980 & 1981 & 1982 & 1983 & 1984 \\
\hline \multirow[t]{4}{*}{$\begin{array}{l}\ln W_{\cdot 78} \ldots \ln W_{\cdot 80} \\
\ln E_{78} \ldots \ln E_{880}\end{array}$} & 1980 & $D_{1}(\mathrm{SS})$ & & $\begin{array}{c}-.029 \\
(.009)\end{array}$ & $\begin{array}{c}-.031 \\
(.012)\end{array}$ & $\begin{array}{c}-.039 \\
(.014)\end{array}$ & $\begin{array}{r}-.055 \\
(.015)\end{array}$ \\
\hline & & $D_{2}(\mathrm{AO})$ & & $\begin{array}{c}.012 \\
(.012)\end{array}$ & $\begin{array}{c}.061 \\
(.016)\end{array}$ & $\begin{array}{c}.048 \\
(.017)\end{array}$ & $\begin{array}{c}.032 \\
(.019)\end{array}$ \\
\hline & & $D_{3}(\mathrm{M})$ & & $\begin{array}{r}-.015 \\
(.029)\end{array}$ & $\begin{array}{c}-.041 \\
(.037)\end{array}$ & $\begin{array}{r}-.035 \\
(.041)\end{array}$ & $\begin{array}{r}-.083 \\
(.046)\end{array}$ \\
\hline & & $D_{4}(\mathrm{R})$ & & $\begin{array}{c}.051 \\
(.007)\end{array}$ & $\begin{array}{l}.170 \\
(.009)\end{array}$ & $\begin{array}{l}.164 \\
(.009)\end{array}$ & $\begin{array}{l}.162 \\
(.011)\end{array}$ \\
\hline \multirow[t]{4}{*}{$\begin{array}{l}\text { In } W_{\cdot 78} \ln W_{\cdot 79} \\
\ln E_{78} \ln E_{\cdot 79}\end{array}$} & 1979 & $D_{1}(\mathrm{SS})$ & $\begin{array}{r}-.020 \\
(.009)\end{array}$ & $\begin{array}{r}-.045 \\
(.011)\end{array}$ & $\begin{array}{r}-.046 \\
(.014)\end{array}$ & $\begin{array}{r}-.054 \\
(.015)\end{array}$ & $\begin{array}{r}-.069 \\
(.016)\end{array}$ \\
\hline & & $D_{2}(\mathrm{AO})$ & $\begin{array}{r}-.000 \\
(.012)\end{array}$ & $\begin{array}{l}.014 \\
(.014)\end{array}$ & $\begin{array}{l}.065 \\
(.017)\end{array}$ & $\begin{array}{l}.053 \\
(.019)\end{array}$ & $\begin{array}{c}.037 \\
(.020)\end{array}$ \\
\hline & & $D_{3}(\mathrm{M})$ & $\begin{array}{c}-.028 \\
(.027)\end{array}$ & $\begin{array}{r}-.030 \\
(.034)\end{array}$ & $\begin{array}{c}-.051 \\
(.041)\end{array}$ & $\begin{array}{r}-.044 \\
(.044)\end{array}$ & $\begin{array}{r}-.089 \\
(.049)\end{array}$ \\
\hline & & $D_{4}(\mathrm{R})$ & $\begin{array}{c}.005 \\
(.006)\end{array}$ & $\begin{array}{l}.054 \\
(.008)\end{array}$ & $\begin{array}{c}.174 \\
(.010)\end{array}$ & $\begin{array}{l}.167 \\
(.010)\end{array}$ & $\begin{array}{l}.165 \\
(.011)\end{array}$ \\
\hline
\end{tabular}

Note: Standard errors are in parentheses.

†SS $=$ simple sale $: A O=$ assets-only sale; $\mathbf{M}=$ merger $\mathbf{R}=$ reorganization . 
The choice of base year makes little difference to the results, and so our discussion will focus on the equations with 1980 as the base year. In the three years after the acquisition (1982-84), wages at firms involved in type 1 (simple sale) acquisitions averaged about 4 percent lower than one would otherwise predict from their pre-1981 wages and employment. Similarly, wages were about 5 percent higher in firms involved in type 2 (assets-only) acquisitions. Firms involved in mergers had wages about 5 percent lower than we estimate they otherwise would be. But in contrast to the previous coefficients, the standard errors of these estimates are sizable. It is worth emphasizing that these last results refer to the average wages in the postmerger firm, controlling for the (weighted average of) premerger wages at both the predecessor and the successor. ${ }^{10}$

Analogous results for the 1982 acquisitions are presented in table 1.6. Although the "control groups" in tables 1.5 and 1.6 are the same, the firms involved in acquisitions are completely different, so that table 1.6 is a nearly independent replication of the previous table. The most important difference is that the coefficient of $D_{3}$ is now tiny (averaging -1.5 percent for 1983 and 1984).

We also reestimated equation (1), restricting the sample to firms employing at least 50 workers. Overall, the coefficients were similar

Table 1.6 Average-Wage Equations for the 1982 Acquisitions

\begin{tabular}{|c|c|c|c|c|c|c|}
\hline \multirow[b]{2}{*}{ Control Variables } & \multirow{2}{*}{$\begin{array}{l}\text { Base } \\
\text { Year }\end{array}$} & \multirow{2}{*}{$\begin{array}{c}\text { Acquisition } \\
\text { Variable }\end{array}$} & \multicolumn{4}{|c|}{ Proportional Effect on Average Wage in: } \\
\hline & & & 1981 & 1982 & 1983 & 1984 \\
\hline \multirow[t]{4}{*}{$\begin{array}{l}\ln W_{7_{78}} \ldots \ln W W_{81} \\
\ln E_{78} \ldots \ln E_{81}\end{array}$} & 1981 & $D_{1}(\mathrm{SS})$ & & $\begin{array}{r}-.035 \\
(.010)\end{array}$ & $\begin{array}{r}-.053 \\
(.012)\end{array}$ & $\begin{array}{r}-.049 \\
(.014)\end{array}$ \\
\hline & & $D_{2}(\mathrm{AO})$ & & $\begin{array}{c}.001 \\
(.012)\end{array}$ & $\begin{array}{c}.042 \\
(.016)\end{array}$ & $\begin{array}{r}.049 \\
(.018)\end{array}$ \\
\hline & & $D_{3}(\mathrm{M})$ & & $\begin{array}{l}.005 \\
(.028)\end{array}$ & $\begin{array}{c}-.005 \\
(.035)\end{array}$ & $\begin{array}{r}-.025 \\
(.041)\end{array}$ \\
\hline & & $D_{4}(\mathrm{R})$ & & $\begin{array}{c}.034 \\
(.007)\end{array}$ & $\begin{array}{l}.114 \\
(.009)\end{array}$ & $\begin{array}{l}.112 \\
(.011)\end{array}$ \\
\hline \multirow[t]{4}{*}{$\begin{array}{l}\ln W_{78} \ldots \ln W_{\cdot 80} \\
\ln E_{78} \ldots \ln E_{80}\end{array}$} & 1980 & $D_{1}(\mathrm{SS})$ & $\begin{array}{c}-.011 \\
(.009)\end{array}$ & $\begin{array}{c}-.043 \\
(.012)\end{array}$ & $\begin{array}{c}-.061 \\
(.013)\end{array}$ & $\begin{array}{r}-.056 \\
(.015)\end{array}$ \\
\hline & & $D_{2}(\mathrm{AO})$ & $\begin{array}{l}.005 \\
(.011)\end{array}$ & $\begin{array}{c}.009 \\
(.015)\end{array}$ & $\begin{array}{c}.049 \\
(.017)\end{array}$ & $\begin{array}{l}.058 \\
(.019)\end{array}$ \\
\hline & & $D_{3}(\mathrm{M})$ & $\begin{array}{r}-.034 \\
(.026)\end{array}$ & $\begin{array}{c}-.011 \\
(.033)\end{array}$ & $\begin{array}{r}-.016 \\
(.038)\end{array}$ & $\begin{array}{r}-.031 \\
(.043)\end{array}$ \\
\hline & & $D_{4}(\mathrm{R})$ & $\begin{array}{c}-.012 \\
(.007)\end{array}$ & $\begin{array}{c}.026 \\
(.009)\end{array}$ & $\begin{array}{c}.108 \\
(.010)\end{array}$ & $\begin{array}{r}.106 \\
(.011)\end{array}$ \\
\hline
\end{tabular}


to those in tables 1.5 and 1.6 but somewhat smaller. They averaged $-1,0$, and -2 percent for type 1, 2, and 3 acquisitions, respectively. We conclude, therefore, that the impact of acquisitions on wages in our sample is small.

\subsection{Employment Equations}

The results of estimating equation (2) for $T=1981$ are summarized in table 1.7. Once again, the choice of base year-1980 (top half of table) or 1979 (bottom half)-has little effect on the results, and we therefore focus on the coefficients from the 1980 base-year equations.

Firms experiencing a simple sale in 1981 had employment in 198284 about 3 percent higher than one would otherwise have predicted. Those involved in assets-only acquisitions had employment about 5 percent lower than would be expected. The employment at firms that merged was indistinguishably different from what we estimate it would have been in the absence of the merger.

Analogous results for the 1982 acquisitions appear in table 1.8. Unfortunately, there are appreciable differences between the coefficients in table 1.8 and those in table 1.7. The effect of a simple sale is now 15 percent (rather than 3 percent), and the effects of the other two

Employment Equations for the 1981 Acquisitions

\begin{tabular}{|c|c|c|c|c|c|c|c|}
\hline \multirow[b]{2}{*}{ Control Variables } & \multirow{2}{*}{$\begin{array}{l}\text { Base } \\
\text { Year }\end{array}$} & \multirow{2}{*}{$\begin{array}{l}\text { Acquisition } \\
\text { Variable }\end{array}$} & \multicolumn{5}{|c|}{ Proportional Effect on Employment in: } \\
\hline & & & 1980 & 1981 & 1982 & 1983 & $198 d$ \\
\hline \multirow[t]{4}{*}{$\begin{array}{l}\ln E_{78} \ldots \ln E_{80} \\
\ln W_{78} \ldots \ln W_{80}\end{array}$} & 1980 & $D_{1}$ (SS) & & $\begin{array}{c}.028 \\
(.008)\end{array}$ & $\begin{array}{l}.026 \\
(.011)\end{array}$ & $\begin{array}{c}.041 \\
(.014)\end{array}$ & $\begin{array}{r}039 \\
(.019)\end{array}$ \\
\hline & & $D_{2}(A O)$ & & $\begin{array}{c}.017 \\
(.006)\end{array}$ & $\begin{array}{r}-.024 \\
(.008)\end{array}$ & $\begin{array}{l}-.048 \\
(.010)\end{array}$ & $\begin{array}{r}-.073 \\
(.014)\end{array}$ \\
\hline & & $D_{3}(\mathrm{M})$ & & $\begin{array}{c}.037 \\
(.007)\end{array}$ & $\begin{array}{c}.036 \\
(.011)\end{array}$ & $\begin{array}{r}-.019 \\
(.013)\end{array}$ & $\begin{array}{r}-.020 \\
(.017)\end{array}$ \\
\hline & & $D_{4}(R)$ & & $\begin{array}{c}-.011 \\
(.010)\end{array}$ & $\begin{array}{r}-.010 \\
(.014)\end{array}$ & $\begin{array}{r}-.060 \\
(.018)\end{array}$ & $\begin{array}{r}-.092 \\
(.024)\end{array}$ \\
\hline \multirow[t]{4}{*}{$\begin{array}{l}\ln E_{78} \ln E_{79} \\
\ln W_{78} \ln W_{79}\end{array}$} & 1979 & $D_{1}(\mathrm{SS})$ & $\begin{array}{c}-.004 \\
(.009)\end{array}$ & $\begin{array}{c}.012 \\
(.013)\end{array}$ & $\begin{array}{c}.016 \\
(.015)\end{array}$ & $\begin{array}{c}.032 \\
(.017)\end{array}$ & $\begin{array}{c}.021 \\
(.022)\end{array}$ \\
\hline & & $D_{2}(A O)$ & $\begin{array}{c}-.003 \\
(.007)\end{array}$ & $\begin{array}{c}.022 \\
(.009)\end{array}$ & $\begin{array}{r}-.017 \\
(.011)\end{array}$ & $\begin{array}{c}-.041 \\
(.013)\end{array}$ & $\begin{array}{r}-.065 \\
(.016)\end{array}$ \\
\hline & & $D_{3}(\mathrm{M})$ & $\begin{array}{c}.014 \\
(.008)\end{array}$ & $\begin{array}{c}.054 \\
(.012)\end{array}$ & $\begin{array}{c}.051 \\
(.014)\end{array}$ & $\begin{array}{c}-.007 \\
(.015)\end{array}$ & $\begin{array}{r}-.005 \\
(.020)\end{array}$ \\
\hline & & $D_{4}(R)$ & $\begin{array}{c}-.063 \\
(.012)\end{array}$ & $\begin{array}{c}-.065 \\
(.015)\end{array}$ & $\begin{array}{r}-.075 \\
(.019)\end{array}$ & $\begin{array}{c}-.124 \\
(.022)\end{array}$ & $\begin{array}{r}-.143 \\
(.027)\end{array}$ \\
\hline
\end{tabular}


types of acquisitions are also a bit larger ( -6 percent and 3 percent, respectively) when one averages over the two postacquisition years (1983 and 1984). Moreover, the merger effects (the coefficients of $D_{3}$ ) are sensitive to the choice of a base year, reaching 8 percent when 1980 rather than 1981 is the base.

This instability across years-and the fact that the results were also sensitive to whether we specified the equation as logarithmic, linear, or (as in tables 1.7 and 1.8) weighted linear-makes us less confident about these results than about the wage results in tables 1.5 and 1.6. Averaging across base years and across the two tables, the three employment effects are roughly 9 percent (simple sales), -5 percent (assets only), and 2 percent (mergers).

As noted in section 1.2, our results use a sample of firms that reported wages and employment in each year. Thus, firms are deleted if they "were born" or "died" during the sample period or if for some reason a whole year's data were missing. To explore the consequences of deleting "deaths" from the sample, we considered a slightly different sample-inclusion criterion. We reran our analysis of employment at firms involved in acquisitions in 1981 (table 1.7), including firms that reported zero employment in 1982 or 1983 through 1984 (in other words, firms that disappeared for at least two years after 1981 and did not

Table 1.8

Employment Equations for the 1982 Acquisitions

\begin{tabular}{|c|c|c|c|c|c|c|}
\hline \multirow[b]{2}{*}{ Control Variable } & \multirow{2}{*}{$\begin{array}{l}\text { Base } \\
\text { Year }\end{array}$} & \multirow{2}{*}{$\begin{array}{c}\text { Acquisition } \\
\text { Variable }\end{array}$} & \multicolumn{4}{|c|}{ Proportional Effect on Employment in: } \\
\hline & & & 1981 & 1982 & 1983 & 1984 \\
\hline \multirow[t]{4}{*}{$\begin{array}{l}\ln E_{78} \ldots \ln E_{\cdot 81} \\
\ln W_{7_{78}} \ldots \ln W_{81}\end{array}$} & 1981 & $D_{1}(\mathrm{SS})$ & & $\begin{array}{c}.067 \\
(.008)\end{array}$ & $\begin{array}{c}.142 \\
(.010)\end{array}$ & $\begin{array}{l}.156 \\
(.013)\end{array}$ \\
\hline & & $D_{2}(A O)$ & & $\begin{array}{c}.056 \\
(.005)\end{array}$ & $\begin{array}{c}-.061 \\
(.007)\end{array}$ & $\begin{array}{r}-.067 \\
(.008)\end{array}$ \\
\hline & & $D_{3}(\mathrm{M})$ & & $\begin{array}{c}.007 \\
(.007)\end{array}$ & $\begin{array}{c}.046 \\
(.009)\end{array}$ & $\begin{array}{l}.015 \\
(.011)\end{array}$ \\
\hline & & $D_{4}(\mathrm{R})$ & & $\begin{array}{c}-.078 \\
(.009)\end{array}$ & $\begin{array}{c}-.128 \\
(.012)\end{array}$ & $\begin{array}{r}-.174 \\
(.016)\end{array}$ \\
\hline \multirow[t]{4}{*}{$\begin{array}{l}\ln E_{78} \ldots \ln E_{\cdot 80} \\
\ln W_{78} \ldots \ln W_{80}\end{array}$} & 1980 & $D_{1}$ (SS) & $\begin{array}{c}.010 \\
(.006)\end{array}$ & $\begin{array}{c}.077 \\
(.011)\end{array}$ & $\begin{array}{c}.157 \\
(.013)\end{array}$ & $\begin{array}{l}.163 \\
(.017)\end{array}$ \\
\hline & & $D_{2}(A O)$ & $\begin{array}{c}.009 \\
(.004)\end{array}$ & $\begin{array}{c}.082 \\
(.007)\end{array}$ & $\begin{array}{c}-.045 \\
(.008)\end{array}$ & $\begin{array}{r}-.057 \\
(.010)\end{array}$ \\
\hline & & $D_{3}(\mathrm{M})$ & $\begin{array}{c}.029 \\
(.005)\end{array}$ & $\begin{array}{c}.051 \\
(.009)\end{array}$ & $\begin{array}{c}.094 \\
(.011)\end{array}$ & $\begin{array}{c}.071 \\
(.013)\end{array}$ \\
\hline & & $D_{4}(\mathrm{R})$ & $\begin{array}{c}.024 \\
(.008)\end{array}$ & $\begin{array}{c}-.073 \\
(.013)\end{array}$ & $\begin{array}{r}-.119 \\
(.016)\end{array}$ & $\begin{array}{r}-.141 \\
(.020)\end{array}$ \\
\hline
\end{tabular}


reappear). Even though this loosening increased the sample considerably (from about 17,000 to about 20,000 ), the coefficients of our acquisition dummy variables did not change appreciably. The largest change was for $D_{3}$, whose coefficient moved from zero (averaging 198284 , top half of table 1.7) to 3 percent with the expanded sample.

\subsection{Conclusions}

Based on our analysis of the MESC data, we find that firms that are part of "simple sales" have postsale wages about 5 percent lower than they would otherwise be, but employment roughly 9 percent higher. Firms that are part of "assets only" acquisitions" have wages about 5 percent higher than they would otherwise be, but employment about 5 percent lower. Mergers are associated with wage declines of about 4 percent and employment growth of about 2 percent.

Two qualifications are in order in viewing these results. First, as we noted in section 1.5, the estimated employment effects are sensitive to which year's acquisitions we study, and to other specification details. Second, our wage measure is the average payroll per worker, and it will therefore deviate from a more ideal wage measure if composition of the work force is changing. In particular, if (as is usually the case) newly hired workers earn less than others in the firm, our wage changes will tend to be negatively related to employment changes. The fact that the effect of each type of acquisition on wages is opposite in sign from its effect on employment is consistent with this interpretation. The estimated effects of mergers on wages are also subject to a different composition effect. If the (relatively high paid) head of the acquired firm leaves following the merger, average wages will fall. Given the small size of our typical firms, a nontrivial share of our estimated wage decline from mergers may be due to such compositional effects.

At this early stage of our research, is difficult to be certain whether these patterns are consequences or merely correlates of the acquisitions. But, at least in our sample, the common public perception that acquisitions provide the occasion to slash wages and employment finds little support.

\section{Notes}

1. For a description of the construction, characteristics, and availability of this file, see Connor, Converse, Heeringa, and Jackson (1984).

2. Predecessor data are aggregated in the relatively rare case of multiple predecessors. Thus, if firm A acquires firm B and later firm C, the predecessor 
field on A's record includes the sum of B and C's employment and payroll up to the time when $B$ is acquired, and then only C's employment and payroll until $C$ is acquired. After $C$ is acquired, succeeding months' (quarters') employment (payroll) data are blank.

3. If the two firms form a new firm, which firm is called the successor is, for our purposes, arbitrary.

4. In scanning the raw data, we noticed that in some cases $P$ fell and $S$ rose just before $P$ became zero. If $P$ in month $T$ was less than half of its value three months earlier, we used $P$ and $S$ in month $T-3$ instead of month $T$ in the above tests. This led to a slight increase in the number of type 3 cases and a corresponding reduction in the number of type 2 cases.

5. Even with the relatively conservative definition of type 3 acquisitions and therefore relatively broad definition of type 2 acquisitions, 20 percent of the type 2 firms in the clean-data file had $S_{T+1}$ exactly equal to $S_{T}$, and another 20 percent had $S_{T+1}$ less than $S_{T}$. The phenomenon of acquiring the assets but not the workers of the predecessor appears, therefore, to be real.

6. To simplify notation, we suppress a subscript for individual firms, but our unit of observation is, of course, firms.

7. We estimated the unweighted equation and then regressed the absolute error on a constant term and premerger employment. We found that both coefficients were consistently positive, suggesting that the error variance increased, but less than proportionately, with the size of the firm.

8. We also interacted the industry dummy variables with $\bar{E}$.

9. One could, of course, hold constant employment and wages through year $T+j-1$ in the equation with year $T+j$ as the dependent variable, but that significantly complicates the interpretation of the results. With that specification, the impact of, say, $D_{k}$ on $\ln W_{T+1}$ would depend on the coefficient of $D_{k}$ in that year's equation plus the indirect effects of $D_{k}$ on $\ln W_{T}$ times the effect of $\ln W_{T}$ on $\ln W_{T+1}$ and of $D_{k}$ on $\ln E_{T}$ times the effect of $\ln E_{T}$ on ln $W_{r+1}$.

10. One might expect that wages at the postmerger firm would move toward the wages at the premerger successor, since the successor has acquired the predecessor. We added a term reflecting the difference in ln-wages between predecessor and successor to the equation (1) specification, but it was never significant. Basically, we cannot tell whether our conjecture is true because of the limited number of mergers in the data.

11. Recall that this category includes mergers involving tiny predecessors, as well as cases in which the predecessor's work force is not acquired.

\section{References}

American Federation of Labor and Congress of Industrial Organizations (AFLCIO). 1987. "Statement" before House Government Operations Subcommittee on Employment and Housing, in Daily Labor Report, 1 April, E1E2.

Ashenfelter, Orley. 1978. Estimating the effect of training programs on earnings. Review of Economics and Statistics 60, no. 1, 47-57. 
Asquith, Paul, Robert Bruner, and David Mullins, Jr. 1986. Merger returns and the form of financing, photocopy. Boston: Harvard University, October.

Bloch, Farrell E. 1979. Evaluating manpower training programs. Greenwich, Conn.: JAI Press.

Connor, Judith, Muriel Converse, Steven Heeringa, and John Jackson. 1984. The Michigan Employment Security Commission longitudinal database of Michigan businesses.’ Ann Arbor: Institute for Social Research, University of Michigan.

Connor, Judith, Steven Heeringa, and John Jackson. 1985. Measuring and understanding economic change in Michigan. Ann Arbor: Institute for Social Research, University of Michigan.

Franks. Julian R., Robert S. Harris, and Colin Mayer. 1988. Means of payment in takeovers: Results for the United States and the United Kingdom. In this volume.

Louis Harris and Associates. 1987. A study of the attitudes of the American people and top business executives toward corporate takeovers, mimeo. Chapel Hill: University of North Carolina Institute for Private Enterprise.

Jensen, Michael C. Takeovers: Folklore and science. Harvard Business Review 85 (November-December 1984): 109-21.

Ruback, Richard S. 1988. Do target shareholders lose in unsuccessful control contests? In this volume.

\section{Comment Geoffrey Carliner}

Brown and Medoff have directed their attention to the market for corporate control of very small firms. The other papers in this volume, and all the controversy surrounding mergers and acquisitions in other media, focus on very large and visible corporations with thousands of employees and price tags in nine figures. Brown and Medoff's study is therefore useful in reminding us that a substantial fraction of the work force is employed by small firms, among which the only hostile takeovers are fights among brothers and sisters over who should run the family business.

As the authors note, the market for ownership of small firms is highly turbulent. According to their data for 1978, 129,932 private sector firms in Michigan were included in the unemployment insurance system, with a total employment of 3.029 million workers (see table 1).' By 1984 only 86,272 of these firms were still contributing to Michigan's unemployment insurance system. The remaining 43,660 firms had

Geoffrey Carliner is executive director of the National Bureau of Economic Research.

1. Unfortunately, all of Brown and Medoff's tables report data for a 20 percent sample of firms with no change in ownership and for the entire population of firms that changed hands. Thus, it is impossible to know the number of characteristics of all the firms in Michigan directly from their tables. 
Table 1

\begin{tabular}{|c|c|c|c|c|c|c|c|}
\hline & \multicolumn{3}{|c|}{ Number of Firms } & \multicolumn{4}{|c|}{ Number of Employees (thousands) } \\
\hline & \multicolumn{2}{|c|}{ All Firms } & \multirow{2}{*}{$\begin{array}{c}\begin{array}{c}\text { Surviving } \\
\text { Firms }\end{array} \\
1978-84\end{array}$} & \multicolumn{2}{|c|}{ All Firms } & \multicolumn{2}{|c|}{$\begin{array}{l}\text { Surviving } \\
\text { Firms }\end{array}$} \\
\hline & 1978 & 1984 & & 1978 & 1984 & 1978 & 1984 \\
\hline No predecessor & 107.675 & 115,930 & 70,025 & 2,369 & 2.319 & 2,031 & 1.891 \\
\hline Reorganization & 12.814 & 13,194 & 9.363 & 115 & 132 & 94 & 103 \\
\hline $\begin{array}{l}\text { Transfer in } \\
\text { ownership }\end{array}$ & 9,443 & 8.492 & 6,884 & 545 & 473 & 512 & 459 \\
\hline Type 1 & 6.166 & 5,376 & 4.055 & 105 & 91 & 85 & 81 \\
\hline Type 2 & 2.815 & 2.665 & 2.391 & 321 & 264 & 311. & 261 \\
\hline Type 3 & 462 & 451 & 438 & 119 & 118 & 116 & 117 \\
\hline Total & 129.932 & 137.616 & 86.272 & 3,029 & 2,924 & 2,637 & 2.453 \\
\hline
\end{tabular}

Source: Brown and Medoff, table 1.3.

presumably gone out of existence. In addition, 6,884 of the surviving firms experienced type 1,2 , or 3 changes in ownership during this period, according to the authors' data.

Although the firms that disappeared tended to be small, the number of workers affected was not small. Total employment in all firms in Michigan in 1978 was 3.029 million. The firms still in existence in 1984 had 2.637 million employees in 1978 . Thus 392,000 employees, or 13 percent of Michigan's private sector employees in 1978, worked for firms that had disappeared by 1984, and an additional 545,000 employees, or 18 percent of all 1978 employees, worked for firms that later changed ownership. ${ }^{2}$

In the regression results shown in tables $1.5-1.8$, Brown and Medoff restrict their sample to firms with data for all seven years, that is, the surviving firms. They recognize, however, that omitting firms that die within a few years may distort their estimates of the effect of ownership transfers on wages and employment. They therefore also ran their employment regressions for a sample including the firms that subsequently disappeared.

2. On top of this loss of jobs, total employment fell in the firms that did survive, from 2.637 million to 2.453 million. The increased employment among new firms of 471 thousand (2.924 - 2.453) did not offset the declines from these two sources, and so on net total employment in Michigan fell during this period.

Changes in Employment, 1978-84 (in thousands)

\begin{tabular}{ll} 
Firm deaths & $2,637-3,029=-392$ \\
Change in firm size & $2,453-2,637=-184$ \\
Firm births & $2,924-2,453=471$ \\
Total change & $2,924-3,029=-105$ \\
\hline
\end{tabular}


A priori, I would have expected firms that change hands to fail more often than other firms, at least for the small stores and service firms that constitute two-thirds of Brown and Medoff's observations. A firm owned by a new, presumably less experienced, owner seems more likely to disappear than an otherwise similar firm that does not change hands, and so I expected the regressions on the full sample to have a smaller coefficient for type 1 firms (simple change in ownership). Brown and Medoff's finding of a 3 percent to 15 percent increase in employment for type 1 firms, even when corporate deaths are included in the regression, is quite surprising.

I also question their estimate that workers in type 3 firms (mergers) experienced wage declines of up to 5 percent. Their calculations of the number of firms and workers involved in transfers of ownership is seriously understated, and it may bias their regression results. As Brown and Medoff recognize, they observe only transfers that occurred between firms in Michigan, since their data source has no information on mergers or acquisitions between Michigan firms and out-of-state firms. For instance, General Motors' acquisition of EDS and Hughes Aircraft would probably not be recorded in their data. Since most Fortune 500 firms are continually buying and selling small firms, Brown and Medoff fail to include a large number of employees who should be counted as working for type 3 firms.

One indication of the size of this problem is the estimate of average firm size. As calculated from their table 1.3, the average number of employees per firm in Michigan in 1984 was 21 . In contrast, national data from the Current Population Survey indicate that 56 percent of private sector employees work for firms with 100 or more employees, and 42 percent are with firms that have 500 or more employees. ${ }^{3}$ It is very unlikely that firms in Michigan are so much smaller than firms in other states. The likely explanation of this difference is that the Michigan data exclude out-of-state employment. Only the Michigan employees of large firms show up in the data used by Brown and Medoff.

The effect of omitting firms with out-of-state mergers is probably to overstate the effect of mergers on the wages and employment of the acquiring firm. When GM buys a small auto parts maker in Illinois, the effect on the number and wages of its employees in Michigan is likely to be negligible. By Brown and Medoff's definitions, however, GM and its Michigan employees should be counted as a type 3 change in ownership in this case.

3. The U.S. Small Business Administration $(1986,229)$. The U.S. data are for private sector wage and salary employees excluding agricultural and private household workers. About 2 percent of the Michigan firms were agricultural. 
In conclusion, I think that the type of analysis presented by Brown and Medoff will lead to a deeper understanding of an ignored aspect of labor market dynamics. Economists have examined longitudinal data on individuals for many years now, and as a result we know a great deal more about the effects of individual characteristics on labor force participation, retirement, and unemployment. Until recently we have had panel data only for the largest corporations, and so we have not been able to study the behavior of small firms over time. Studies like this one will offer important insights into the ways in which industries grow and contract. They have little to do, however, with the hostile takeovers and other ownership changes among large firms that are the subject of the other chapters in this volume.

\section{Reference}

U.S. Small Business Administration. 1986. The state of small business. Washington, D.C.: GPO.

\section{Comment Henry S. Farber}

Given the public and professional perception of mergers and acquisitions as involving one Goliath joining or swallowing another, the analysis presented by Brown and Medoff serves as a refreshing reminder that the modal merger or acquisition actually involves two Davids rather than two Goliaths. When viewed in this context, the popular image of a corporate raider taking over a large and probably unionized company, abrogating or renegotiating existing implicit or explicit labor contracts, and reducing both wages and employment seems to be less applicable than one might have thought.

Brown and Medoff conclude from their analysis of data from the Michigan unemployment insurance system administrative records that there are only small and sometimes positive changes in wages and employment on average following a merger or acquisition. Although the analysis is straightforward and the authors are candid about its limitations, a few points bear closer examination.

The central limitation of the data is that it deals exclusively with employment in Michigan. The implications of this go substantially beyond the usual caveat that Michigan may be different from other states. In particular, many firms have business operations that span state

Henry S. Farber is professor of economics at the Massachusetts Institute of Technology and a research associate of the National Bureau of Economic Research. 
boundaries, so that looking strictly at Michigan employment is likely to give a misleading picture of both the employment size distribution of firms involved in mergers and acquisitions and the employment effects of mergers and acquisitions. This point is obviously more important for larger firms because they are more likely to have operations that cross state boundaries.

This limitation of the data interacts in a serious way with the central classification scheme used by Brown and Medoff. They break mergers and acquisitions into three categories that are potentially affected by examining only Michigan employment. For example, simple sales (type 1 events) are said to occur when the successor firm has no prior Michigan employment. But an out-of-state firm with substantial employment could acquire a Michigan firm in what is really a merger with or acquisition by a previously existing firm.

More generally, the authors' classification scheme is not entirely satisfactory, as they recognize. Aside from the caveat noted in the previous paragraph, the classification of simple sales seems straightforward. Nevertheless, the distinction between "assets-only" acquisitions and mergers that retain the workers is less convincing. Since an important part of what Brown and Medoff are interested in is the employment effect of a merger or acquisition, using employment changes to classify the event does not seem appropriate. This classification scheme leads to problems later when the authors investigate the employment effects of the three types of acquisitions. It is not surprising that they find type 2 (assets-only) mergers and acquisitions have small negative employment effects. The effects were defined not to have positive employment changes. Similarly, it is not surprising that type 3 (assets and work forces) mergers and acquisitions have positive employment effects. The effects here were defined not to have negative employment changes.

The method of analysis is quite straightforward. Both the wage and the employment level equations are estimated conditional on past wage and employment levels, and dummy variables are included for each of the three types of events. The coefficients of these dummy variables are interpreted as the effects of each of the events on wages and employment. With regard to wage changes, this analysis is not bad. The finding that average wages drop by 3 to 5 percent after simple sales is interesting, and it would be considered by some to be substantial. The finding that wages seem to be 3 to 5 percent higher after type 2 mergers and acquisitions is interesting, but it cannot get at what happens to the wages of the acquired workers precisely because type 2 mergers and acquisitions are defined as cases in which there are no acquired workers. The mixed results, though with predominantly negative point estimates obtained for the type 3 mergers and acquisitions, when combined 
with the consistently significantly negative wage effects found for simple sales, serve as evidence that acquired workers receive lower wages after a merger or acquisition. Whether the magnitudes involved are large or small is a matter of judgment.

With regard to employment levels, the analysis is less convincing. This is largely because the classification system obscures the true effect of mergers and acquisitions. The interesting question is how prevalent the negative employment effects are relative to the positive employment effects. The method of constructing the data almost guarantees that type 2 mergers and acquisitions will have nonpositive employment changes, while type 3 mergers and acquisitions will have nonnegative employment changes. Econometrically, the dummy variables are defined in a way that ensures their correlation with the dependent variable and hence with the error term in the regression. It might be more useful not to make a distinction between type 2 and type 3 mergers and acquisitions.

If no distinction were made between the two types, the coefficient of the "non-simple sale" dummy variable might be a useful summary statistic for the employment effects of these events. On the basis of the numbers presented, a very crude estimate of the overall employment effect can be derived as a weighted average of the estimated effects for each type of event. By the data in table 1.3, type 2 mergers and acquisitions account for approximately 70 percent of the employment in the two types of mergers and acquisitions in total. Using the results in table 1.7, I assume an average employment effect of type 2 mergers and acquisitions of -.04 and an average employment effect of type 3 mergers and acquisitions of +.04 . Weighting these by .7 and .3 , respectively, yields an admittedly crude overall effect of $.7(-.04)+.3(.04)=-0.016$. Of course, this calculation does not account for any systematic bias in the estimates in table 1.7 induced by the endogenous categorization scheme, but it does suggest that the average employment effects are close to zero.

One useful modification of the analysis would be to estimate the wage and employment equations as straightforward differences, rather than as levels equations with lagged dependent variables. This alteration would make interpreting the results very easy, and an additional column in table 1.4 with average proportional changes in employment between $T-3$ and $T+1$ would serve as a useful summary of the employment effects. A table similar to table 1.4 for wages could also be constructed.

Overall, Brown and Medoff present some fascinating facts, although I wish they had presented simpler summary statistics and frequency distributions for their data. I find the analysis of wage changes to be 
fairly convincing, and we have the interesting finding that wages do indeed drop on average after mergers or acquisitions. The analysis of employment changes is less convincing. The distinction between type 2 and type 3 events is artificial, and it serves only to confuse the empirical analysis. In addition, the exclusion of non-Michigan employment must add considerable noise to the employment change analysis.

A final comment concerns the relevance of the authors' analysis to the general debate on the causes and effects of mergers and acquisitions. Obviously, the debate has focused on the very large events. Brown and Medoff's sample is very heavily weighted toward much smaller events. On this basis their analysis and the general debate are on different planes. Nonetheless, although the authors may have little to say about Carl Icahn and compatriots directly, the phenomenon they do address is important, and their study is a useful contribution to our limited stock of knowledge of the smaller acquisitions. 
